\title{
Evaluation of fungicides for management of anthracnose disease of black gram (Vigna mungo I.) in growing areas of district Jhansi of Bundelkhand region
}

Adesh Kumar*

Krishi Vigyan Kendra, Bharari, Jhansi-284002 (Uttar Pradesh), India

Roomi Rawal

Central Agroforestry Research Institute, Jhansi-284003

Nishi Roy

Krishi Vigyan Kendra, Bharari, Jhansi-284002 (Uttar Pradesh), India

Atik Ahamad

Krishi Vigyan Kendra, Bharari, Jhansi-284002 (Uttar Pradesh), India

Hitesh Kumar

Department of Genetics and Plant Breeding, Banda University of Agriculture and Technology, Banda-210001 (Uttar Pradesh), India

*Corresponding author. E-mail: adeshpp@gmail.com

\begin{abstract}
Black gram (Vigna mungo L.) growing areas of district Jhansi coming under Bundelkhand region of Uttar Pradesh were surveyed during Kharif 2018 for the occurrence of anthracnose disease of black gram. A total of 22 villages were visited under six blocks of Jhansi during this period. Blockwise comparison of the survey in Jhansi revealed that less mean disease incidence $(10 \%)$ and severity $(4.0 \%)$ occurred in the Chirgaon block. Highest disease incidence $(24 \%)$ and severity $(12 \%)$ were observed in block Moth. The block Bangra, Babina, Badagaon, and Bamour secured disease incidence 23.5, 20, 16.44 and $15 \%$ and severity $15.14,12,7.44$ and $8.5 \%$ respectively. Nine fungicides (viz. folicur@0.1\%, tilt @0.1\%, natio@0.0.5\%, saaf@0.2\%, bavistin@0.2\%, dithane Z-78@0.2\%, amistar top, kavach@0.2\% and blitox@0.2\%) were tested against anthracnose disease of black gram under field condition. Among them, seed treatment with carbendazim@ $3 \mathrm{gram} / \mathrm{kg}$ seed and foliar spray of mixture of azole and strobilurin group T3natio@0.05 ( tebuconazole + trifloxystrobin) and T7-amistar top@0.1\% (azoxystrobin+ difenoconazole) were found significantly (at $0.05 \%$ ) superior over the rest of treatments, both showed minimum $(6 \%)$ disease severity with maximum $(78.51 \%)$ disease control. Significant (at $0.05 \%)$ increase in yield $(47.5 \%)$ also observed in both treatments T3 and T7. The treatment T1- Spray of Folicur@0.1\%, T2- Spray of Tilt @0.1\%, T4- Spray of Saaf@0.2\%, T5- Spray of Bavistin@0.2\%, T8- Spray of Kavach@0.2\%, T9- Spray of Blitox@0.2\% also showed good results in reducing the black gram anthracnose disease severity per cent $(64.29,57.14,64.28,57.14,71.42$ and 64.28 and also increased the yield per cent $37.5,35,42.5,36.25,45$ and 45 respectively.
\end{abstract}

Keywords: Anthracnose disease, Black gram, Fungicide, Disease incidence, Disease severity

\section{INTRODUCTION}

Urad (Black gram), the 3rd important pulse crop in India is cultivated over an area of 5.44 Mha (kharif + rabi) and recorded production of $3.56 \mathrm{Mt}$ at a productivity level of $655 \mathrm{~kg} / \mathrm{ha}$. Major black gram growing states are Andhra Pradesh, Bihar, Karnataka, Maharashtra, Madhya Pradesh, Orissa, Rajasthan, Tamil Nadu, Uttar Pradesh and West Bengal. In Uttar Pradesh, black gram is cultivated in an area of 6.14 lakh ha with a production of 3.14 lakh tons (Anonymous, 2018a). In Jhansi district, black gram is cultivated in 80.214 ha land

\section{Article Info}

https://doi.org/10.31018/

jans.vi.2257

Received: April 5, 2020

Revised: May 4, 2020

Accepted: May 10, 2020

\section{How to Cite}

Kumar, A. et al. (2020). Evaluation of fungicides for management of anthracnose disease of black gram (Vigna mungo I.) in growing areas of district Jhansi of Bundelkhand region. Journal of Applied and Natural Science, 12 (2): $110-114$.

https://doi.org/10.31018/ jans.vi.2257 
black gram growing states of India in mild to severe form and in tropical and subtropical areas causes considerable damage by reducing seed quality and yield. Anthracnose disease symptoms are circular, black, sunken spots with a dark centre and bright red-orange margins on leaves. The yield loss due to anthracnose is depended on the stage of infection, genotypes and environmental conditions. In India, this disease was earlier considered to be of the minor problem, but with the intensification of black gram cultivation, its severity has gradually increased in some part of the country. Colletotrichum gloeosporioides caused 80 to $100 \%$ yield losses under the favorable condition in bean crop (Shao and Teri 1985; Sharma et al., 2007). For management of fungal diseases, fungicides have an important role to control plant fungal diseases. Fungicides inhibit the growth of the fungi under in vitro and in vivo condition (Bashir et al.1985, Khan et al. 2005, Shukla et al. 2014);). They have a different mode of action to control fungal growth. Azoxystrobin fungicides have the potential to inhibit mitochondrial respiration and blocking the cytochrome bc1 complex can be used to control Colletotrichum gloeosporioides pathogen causing anthracnose disease in green gram (Chaudhari and Gohel, 2016). Considering the rising and devastating nature of the anthracnose disease and economic loss of the crop in this area, an attempt was made to evaluate the newer fungicides under field condition for the control of this important anthracnose disease in Jhansi district of Uttar Pradesh.

\section{MATERIALS AND METHODS}

Survey of different blocks of Jhansi district: Different black gram growing areas of Jhansi district viz. Bangra, Bbina, Badagaon, Chirgaon, moth and Bamour blocks were surveyed in the months of July- August during kharif 2018. At each location, anthracnose disease incidence was recorded by counting the number of infected plants in a square meter area at all the four corners as well as the centre of the field. The disease severity was recorded with the help of a 0-9 scale (Table 1).

Evaluation of fungicides against black gram anthracnose under field condition: The experiment was conducted at NICRA village Birgua, block Badagaon which come under district Jhansi with nine fungicides (Table-2). Black gram cultivar (T 9) was grown in farmer field with recommended package and practices. Seeds were treated with carbendazim $3 \mathrm{~g} / \mathrm{kg}$ seeds, prior to sowing. The experiment was conducted ( under natural condition) in a Randomized Block Design with 3 replications having plot size of $4 \times 4 \mathrm{~m}$ and spacing between row to row and plant to plant as $30 \mathrm{~cm}$ and $10 \mathrm{~cm}$, respectively. Foliar sprays of fungicides were given at the initiation of the disease. Twenty plants were selected randomly and labelled from each plot for scoring the disease severity. Disease severity was scored for the infected plant with a $0-9$ scale (Table 1 ) as given by (Mayee and Dattar,1986) after 7 days of fungicide spray. The seed yield ( $\mathrm{kg} / \mathrm{ha}$ ) was also recorded.

Treatments: Ten treatments were applied in this experiment: T1- Spray of Folicur@0.1\%, T2Spray of Tilt @0.1\%, T3- Spray of Natio@0.5\%, T4- Spray of Saaf@0.2\%, T5- Spray of Bavistin@0.2\%, T6- Spray of Dithane Z-78@0.2\%, T7Spray of Amistar Top, T8- Spray of Kavach@0.2\%, T9- Spray of Blitox@0.2\%, T10Control.

Statistical analysis: Critical difference was calculated between different treatments with respect to disease severity and yield. The significant difference between the two means found out with the help of CD $0.05 \%$.

\section{RESULTS AND DISCUSSION}

Survey of different blocks of Jhansi district: Anthracnose disease is an important constraint in the cultivation of kharif black gram of Jhansi district. Black gram growing region of Jhansi district viz. Bangra, Babina, Badagaon, Chirgaon, Moth and Bamour blocks were surveyed in the months of July- August during kharif 2018. A total of 22 locations were visited in district and disease was invariably present in all the blocks during kharif 2018 (Table-3). Block wise comparison of the survey in Jhansi revealed that less mean disease incidence $(10 \%)$ and severity $(4.0 \%)$ occurred in the Chirgaon block. Highest disease incidence $(24 \%)$ and severity (12\%) were observed in block moth (figure-1). The block bangra, Babina, Badagaon, and Bamour secured disease incidence $23.5,20,16.44$ and $15 \%$ and severity $15.14,12,7.44$ and $8.5 \%$ respectively. Maximum

Table 1. Disease Rating Scale for black gram anthracnose.

\begin{tabular}{ll}
\hline Scale & Description \\
\hline 0 & No symptoms on leaves. \\
1 & Small size lesions covering $1 \%$ or less of leaf area. \\
3 & Small size lesions covering $1-10 \%$ of leaf area. \\
5 & Lesions size big but not coalescing, covering $11-25 \%$ of the leaf area. \\
7 & Lesions on leaves covering $26-50 \%$ of leaf area. Cankers on stem and pod infection. \\
9 & Lesions on leaves covering $51 \%$ or more of leaf area. Defoliation of leaves, deep cankers on stem \\
& and pods, blighting of plant occurs.
\end{tabular}

(Source: Mayee and Dattar,1986) 
Kumar, A. et al. / J. Appl. \& Nat. Sci. 12(2): 110 - 114 (2020)

Table 2. Fungicides used in this study for the control of anthracnose disease of black gram.

\begin{tabular}{|c|c|c|c|c|}
\hline Fungicides & Chemical group & $\begin{array}{l}\text { Active } \\
\text { ingredient }\end{array}$ & $\begin{array}{l}\text { Concentra- } \\
\text { tion (\%) }\end{array}$ & $\begin{array}{l}\text { Formula- } \\
\text { tion }\end{array}$ \\
\hline Folicur & Azole & Tebuconazole & 25.9 & EC \\
\hline Tilt & Azole & Propiconazole & 25 & EC \\
\hline Natio & Mixture of Azole and Strobilurin & Tebuconazole + Trifloxystrobin & $50+25$ & WG \\
\hline SAAF & $\begin{array}{l}\text { Mixture of benzimidazole and } \\
\text { Carbamate }\end{array}$ & Carbendazim+ Mancozeb & $12+63$ & WP \\
\hline Bavistin & benzimidazole & Carbendazim & 50 & WP \\
\hline Dithane Z-78 & Carbamate & Zineb & 70 & WP \\
\hline Amistar Top & Mixture of Azole and Strobilurin & Azoxystrobin+ Difenoconazole & $18.2+11.4$ & WM \\
\hline Kavach & Chloronitrile & Chlorothalonil & 75 & WP \\
\hline Blitox & Copper & Copper Oxychloride & 50 & WP \\
\hline
\end{tabular}

Table 3. Field based assessment of anthracnose disease of black gram growing area in Jhansi district during the period of Kharif 2018.

\begin{tabular}{|c|c|c|c|c|c|}
\hline S.N. & Block & Village & Variety & Disease Incidence \% & Disease Severity\% \\
\hline 1. & Bamour & Bilati & Local & 12 & 5 \\
\hline 2. & Badagaon & Lakara & Local & 16 & 6 \\
\hline 3. & Badagaon & Bhojla & Local & 20 & 10 \\
\hline 4. & Badagaon & Behta & Azad urd-2 & 16 & 8 \\
\hline 5. & Badagaon & Baltada & Local & 24 & 10 \\
\hline 6. & Badagaon & Booda & Azad urd-2 & 10 & 4 \\
\hline 7. & Badagaon & Kot & Uttara & 12 & 6 \\
\hline 8. & Badagaon & Ghandinagar & Uttara & 16 & 10 \\
\hline 9. & Badagaon & Padri & Local & 24 & 10 \\
\hline 10. & Badagaon & Birgua & Uttara & 10 & 5 \\
\hline 11. & Babina & Dhikauli & T9 & 20 & 12 \\
\hline 12. & Chirgaon & Sinthari & T9 & 10 & 4 \\
\hline 13. & Bangra & Bdawali & T9 & 16 & 6 \\
\hline 14. & Bangra & Ghurat & T9 & 20 & 12 \\
\hline 15. & Bangra & Palra & Local & 22 & 14 \\
\hline 16. & Bangra & Kachwada & Local & 34 & 22 \\
\hline 17. & Bangra & Magarwar a & T9 & 26 & 16 \\
\hline 18. & Bangra & Patha-Karka & Local & 22 & 12 \\
\hline 19. & Bangra & Tejpura & Local & 26 & 12 \\
\hline 20. & Bangra & Chokri & Local & 20 & 18 \\
\hline 21. & Moth & Divyapur & Local & 24 & 12 \\
\hline 22. & Bamour & Khadani & Local & 18 & 12 \\
\hline
\end{tabular}

Table 4. Anthracnose disease severity per cent and black gram yield after foliar spray of different treatments under field condition.

\begin{tabular}{lll}
\hline Treatment & Disease Severity \% & Yield (q/ha) \\
\hline T1 & $10^{*}$ & $5.5^{*}$ \\
T2 & $12^{*}$ & $5.4^{*}$ \\
T3 & $6^{*}$ & $5.9^{*}$ \\
T4 & $10^{*}$ & $5.7^{*}$ \\
T5 & $12^{*}$ & $5.45^{*}$ \\
T6 & $14^{*}$ & $5.3^{*}$ \\
T7 & $6^{*}$ & $5.9^{*}$ \\
T8 & $8^{*}$ & $5.8^{*}$ \\
T9 & $10^{*}$ & $5.8^{*}$ \\
T10 & 28 & 4 \\
SD & 6.32 & 0.57 \\
SE & 1.99 & 0.18 \\
CD 0.05\% & 3.65 & 0.32 \\
\hline
\end{tabular}

** and ${ }^{*}$ indicate significance at $p<0.01$ and $p<$ 0.05 , respectively.

disease incidence (34\%) and severity (22\%) occurred in the village kuchwada come under black bangra however, minimum disease incidence
$(10 \%)$ and severity $(4.0 \%)$ were observed in the two village Baltada and Sinthari come under Badagaon and Chirgaon blocks respectively. Black gram new cultivars and old cultivars also play a major role in disease development in black gram. Lowest mean disease incidence (15.60\%) and severity $(8.3 \%)$ was observed in new recommended cultivars as compared to local cultivars (Figure2). The highest mean disease incidence $(21.83 \%)$ and severity $(11.91 \%)$ was observed in local cultivars.

Evaluation of fungicides against black gram anthracnose disease under field condition: In the present study, all the treatments were found significantly (at $0.05 \%$ ) effective in reducing anthracnose disease severity per cent than control (no spray) (Table 4). Among them, mixture of azole and strobilurin group T3- natio@0.05 ( tebuconazole + trifloxystrobin) and T7-amistar top@0.1\% (azoxystrobin+ difenoconazole) were found significantly (at $0.05 \%$ ) superior over the rest of treatments, and both were showing minimum 


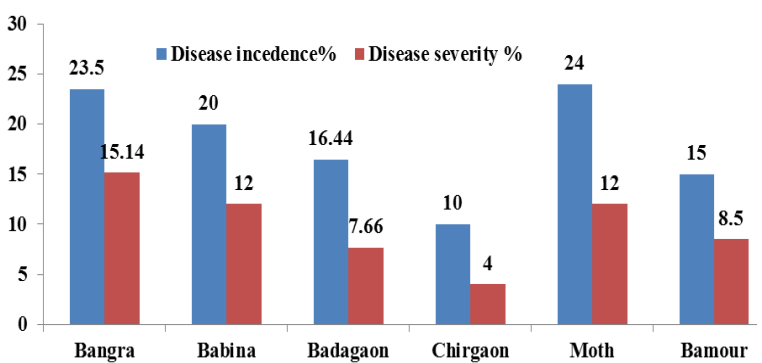

Fig. 1. Anthracnose disease incidence and severity in different blocks of district Jhansi during survey in the period of Kharif, 2018.

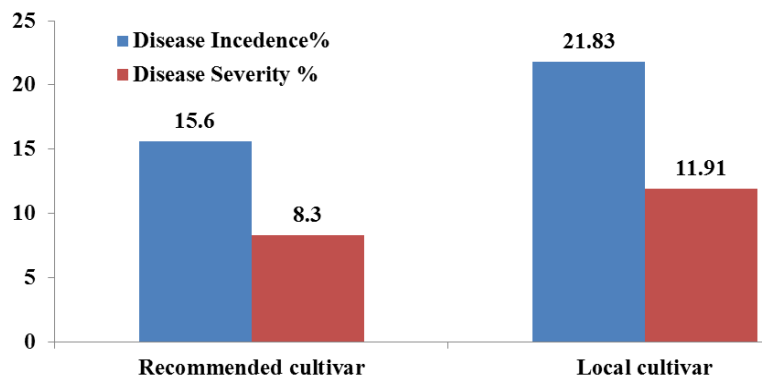

Fig. 2. Anthracnose disease incidence and severity in recommended and local cultivars during survey in the period of Kharif 2018.

$(6 \%)$ disease intensity with maximum $(78.51 \%)$ disease control. The mixture of fungicides was more effective due to their different mode of action for control of anthracnose disease of black gram. Significant (at $0.05 \%$ ) increase in yield $(47.5 \%)$ also observed in both treatments T3 and T7 (Figure 3and4). The treatment T1- Spray of Folicur@0.1\%, T2- Spray of Tilt @0.1\%, T4- Spray of Saaf@0.2\%, T5- Spray of Bavistin@0.2\%, T8 - Spray of Kavach@0.2\%, T9- Spray of Blitox@0.2\% also showed good result in reducing the black gram anthracnose disease severity per cent $64.29,57.14,64.28,57.14,71.42$ and 64.28 and also increased the yield per cent $37.5,35$, $42.5,36.25,45$ and 45 respectively (Figure 3and4). It was also observed that among the treatments T6- Spray of Dithane Z-78@0.2\% showed the lowest disease severity reduction per cent 50 with yield increase per cent 32.5. Chaudhari and Gohel (2016) completely agreed with our study, who observed that anthracnose disease of mungbean can be controlled with seed treatment by fungicide (thiram $75 \mathrm{SD}, 3 \mathrm{~g} / \mathrm{kg}$ seeds) + two foliar sprays at 15 days interval starting from initiation of disease with trifloxystrobin + tebuconazole (75 WG), 0.075 per cent or with carbendazim + mancozeb (75 WP), 0.075 per cent. Approximately, similar result was observed by Ingle et al. (2014). They applied two sprays of tebuconazole $(0.1 \%)$ at 25 days interval for management of Colletotrichum leaf spot of soybean followed by propiconazole $(0.1 \%)$, hexaconazole $(0.05 \%)$ and azoxystrobin $(0.1 \%)$. Ahiladevi and Prakasam (2013) tested bioefficacy

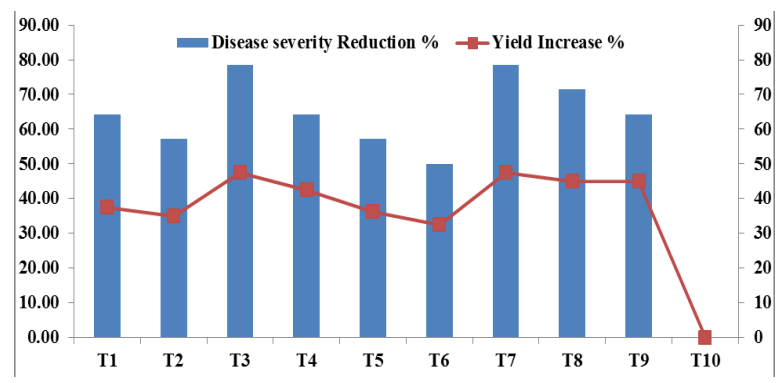

Fig. 3. Anthracnose disease severity reduction and yield increase per cent after foliar spray of nine fungicides under field condition.

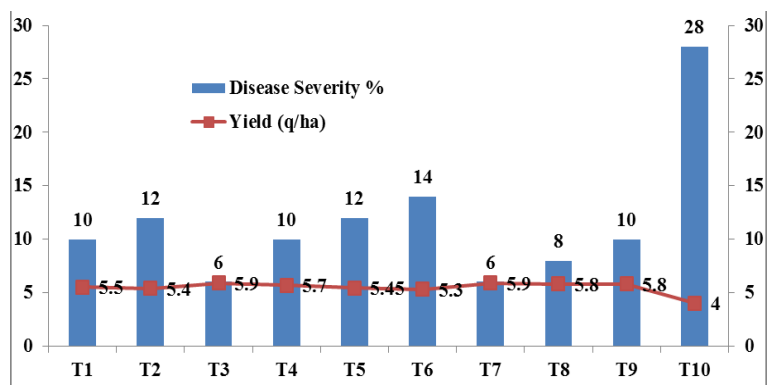

Fig. 4. Anthracnose disease severity per cent and black gram yield after foliar spray of nine fungicides under field condition.

of azoxystrobin 25 SC with different concentrations $(100,125$, and $150 \mathrm{~g}$ a.i./ha) against chilli anthracnose disease under field conditions and found maximum control of disease with $150 \mathrm{~g}$ a.i./ ha. Kumbhar and More (2013) studied the efficacy of five fungicides of triazole group viz., tebuconazole $25.9 \mathrm{EC}$, difenconazole $25 \mathrm{EC}$, hexaconazole $5 \mathrm{SC}$, tricyclazole $75 \mathrm{WP}$ and propiconazole 25 EC against fruit rot disease of chilli. Fungicide, tebuconazole appeared the most effective among the fungicides tested, with a reduction in fruit rot incidence and intensity to the tune of $69.96 \%$ and $73.56 \%$, respectively over unsprayed control. Subedi el al. (2015) observed that the higher anthracnose Percent Disease Control (PDC) and Percent Yield Increase (PYI) were estimated in the plot treated with SAAF (Carbendazim 12\% + Mancozeb $63 \%$ ) followed by Mancozeb fungicides. Jagtap et al. (2013) conducted an experiment to control C. truncatum causing anthracnose/ pod blight of soybean with fungicides and found carbandazim, $0.1 \%$ recorded minimum disease intensity $(19.55 \%)$ and pod infection $(9.63 \%)$, with highest seed yield (2605 kg/ha) followed by mancozeb, $0.1 \%$ which recorded the minimum disease intensity $(21.50 \%)$ and pod infection $(10.78 \%)$.

\section{Conclusion}

Anthracnose disease is an important constraint in the cultivation of kharif black gram which is invariably present in district Jhansi. After the survey, it was also observed that new recommended cultivars (Azad urd 2 and Uttara) showed less anthracnose disease incidence and severity as compared 
to local cultivars. For the management of this disease, seed treatment with carbendazim @3gram/ $\mathrm{kg}$ seed and foliar spray of T3- natio@0.05 (tebuconazole + trifloxystrobin) and T7-amistar top@0.1\% (azoxystrobin+ difenoconazole) were found significantly (at $0.05 \%$ level of significance ) superior over the rest of treatments, both (T3 and T7) were showing minimum (6\%) disease intensity with maximum $(78.51 \%)$ disease control. Significant increase in yield (47.5\%) was also observed in both treatments T3- natio@0.05 (tebuconazole + trifloxystrobin) and T7-amistar top@0.1\% (azoxystrobin+ difenoconazole). In Jhansi district, there is a limited application of fungicides for Kharif season crop. The farmers can use the abovesaid fungicide with single spray to control of anthracnose disease of black gram.

\section{REFERENCES}

1. Ahiladevi, P. and Prakasam, V. (2013). Bioefficacy of azoxystrobin $25 \mathrm{SC}$ along with bioagents against chilli anthracnose disease under field conditions. Pest Manage. Horti. Ecosys. 19(1):57-62.

2. Anonymous (2018a). Pulses revolution from food to nutritional security. Crops division government of India ministry of agriculture and farmers welfare department of agriculture, cooperation and farmers welfare Krishi Bhavan, New Delhi - 110001.

3. Anonymous (2018b). Economics and statistics division state planning institute, planning department, Uttar Pradesh, Lucknow, In: Sankhikya Patrika District Jhansi. Page no. 37

4. Bashir, M., Alam, S.S., Qureshi, S.H. and Malik, B. A. (1985). Control of mungbean anthracnose by foliar fungicides. Pakistan J. Agric. Res. 6:173-175.

5. Chaudhari, K.A and Gohel, N.M. (2016). Management of anthracnose disease of mungbean through new fungicidal formulations. J. Pure Appl. Microbiol. 10(1): 691-696.

6. Ingle, Y.V., Patil, C.U. and Ingle, T.K. (2014). Effect of fungicides and plant resistance activator on Colletotrichum leaf spot of soybean. The Bioscan. 9 (3):1187-1190

7. Jagtap, G.P., Gavate, D.C. and Dev, U. (2013). Management of Colletotrichum truncatum causing anthracnose/ pod blight of soybean by fungicides. Indian Phytopath. 66(2):177-181.

8. Khan, A.A., Khan, R.U. and Singh, R. (2005). Management of Cercospora leaf spot and anthracnose diseases of mungbean by fungicides. Ann. Plant Prot. Sci. 13:465-529.

9. Kumbhar, C.T. and More, S.M. (2013). Efficacy of triazole fungicides in controlling fruit rot of chilli. Int. J. Pl. Prot. 6(2):257-261.

10.Majid, S. (1953). Annals Report of Department of Agriculture, Assam for the year 1951-1952 and 19521953. The Grow More Food Campaign, 2:1-112.

11.Mayee, C.D. and Datar, V.V. (1986). "Phytopathometry" Technical Bulletin-I, Marathawada Agricultural University, Parbhani, India, pp. 146.

12.Shao, F.M. and Teri, J.M. (1985). Yield losses in Phaseolus beans induced by anthracnose in Tanzania. Trop. Pest Manag. 31:60-62.

13.Sharma, P.N, Ahmad B., Sharma O.P., Pathania, A. and Sharma, P. (2007). Pathological and molecular diversity in Colletotrichum lindemuthianum (bean anthracnose) across Himachal Pradesh- A northwestern Himalayan state of India. Australas. Plant. Path. 36:191-197.

14.Shen, Y.M., Liu, H. L., Chang, S.T. and Chao, C.H. (2010). First report of anthracnose caused by Colletotrichum acutatum on mungbean sprouts in Taiwan. Plant Dis. 94:131.

15.Shukla, V., Baghel, S., Maravi, K. and Singh, S.K. (2014). Yield loss assessment in mungbean [Vigna radiata (L.)Wilczek] caused by anthracnose [Colletotrichum truncatum (schw.) Andrus and moore]. Bioscan, 9:1233-1235.

16.Subedi, S. Gharti, D. B., Neupane, S. and Ghimire, T. (2015). Management of Anthracnose in Soybean using Fungicide. J. Nepal Agri. Res. Coun. 1: 29-32. 